\title{
Hydrogeochemical Evaluation of Groundwater in Parts of Shamal, Northern Qatar
}

\author{
Latifa Shaheen Al-Naimi \\ Department of Chemistry and Earth Sciences, Qatar University, Qatar \\ Tel: 974-6658-5656_E-mail: latifa2@qu.edu.qa
}

Tochukwu Innocent Mgbeojedo (Corresponding author)

Professional Founder Geological Consulting, Qatar

Tel: 974-6616-3603Ｅ-mail: toomgbeojedo@gmail.com

Received: March 8, 2018 Accepted: March 23, 2018 Published: April 23, 2018

doi:10.5296/emsd.v7i2.13046ＵRL: https://doi.org/10.5296/emsd.v7i2.13046

\begin{abstract}
Hydrogeochemical analyses of groundwater samples in Shamal area were undertaken to assess the groundwater chemistry of the area and hence determine its suitability for irrigation and other purposes. Thirteen groundwater samples were freshly collected from different functional wells in the area and were analyzed for different physico-chemical parameters. The analyzed parameters include TDS, EC, major cations and anions. The water quality study shows that EC ranges from 7891.88-20 736.84 $\mu \mathrm{S} / \mathrm{cm}$, TDS values range from 5050.80-13 $271.58 \mathrm{mg} / \mathrm{l}$. Analytical study of water samples shows that sodium varies from 1316.38-3432.39 mg/l, calcium varies from 300.81-799.93 $\mathrm{mg} / \mathrm{l}$, magnesium varies from 126.66-381.81 mg/l, potassium varies from 74-181.02 mg/l, chloride values range from 2177.75-6058 mg/l, sulphate values range from 743.87-2448.79 mg/l and bicarbonate values range from 23.13-240.3 mg/l. The high concentrations of sodium and chloride ions are indicators of saline water intrusion. The analyses of the hydrogeochemical ratios were also done to highlight the groundwater genesis and origin of mineralization. The water samples were analyzed for suitability for irrigation using various classification criteria and mathematical formula. The results from analysis of KR, SAR, SSP, PS, EC and \% Na all indicate that the water in the area is unfit for use in irrigation.
\end{abstract}

Keywords: Groundwater Chemistry, Water Quality, Physico-chemical Parameters, Hydrogeochemical Ratios, Groundwater Samples 


\section{Introduction}

About $80 \%$ of the earth's surface is covered by water, yet qualitatively $97 \%$ of this vast natural resource falls unfit for human use (Rai, 2004). Fresh water for life is $0.6 \%$ of the total water budget with the bulk of it tied up in groundwater (Gleeson et al., 2012). It was estimated that about $1000 \mathrm{~km}^{3}$ of the world's aggregated groundwater is abstracted annually. Approximately $67 \%$ is used for irrigation, $22 \%$ for domestic, and $11 \%$ for industrial purposes (Siebert et al., 2010; AQUASTAT, 2011). Groundwater quality depends on several factors including lithology, chemical composition of the aquifers, climatic conditions prevailing during formation, quantity of water available in the aquifer and its rate of circulation (Todd and Mays, 2005).

The chemical properties of water are as important as the physical properties and determine its usefulness for industry, agriculture, or the home. The study of water chemistry also gives important indications of the geologic history of the enclosing rocks, the velocity and direction of water movement (Fetter, 1994).

Water scarcity and unavailability stemming from accelerating demand for water over the years in different parts of the world has also been exacerbated by the menace of water pollution, degradation, contamination and the incursion of sea water into aquifers (saline intrusion) as is noticeable within Qatar and most arid peninsulas.

The arid country of Qatar is situated on the eastern part of the Arabian Peninsula and bounded by the Persian Gulf from East, North and West, with Saudi Arabia as its only land border in the South. The low mean annual rainfall (about 80-120mm) and little groundwater resources are insufficient for the population of about 2.4 million, hence the reliance on desalination of sea water to meet the water needs. Most of the existing groundwater aquifers have suffered from excessive abstraction in the last couple of decades, causing a significant decline in groundwater levels, drastic changes to water quality occasioned by the upsurge of the deeper saline waters into the upper, fresher groundwater zones.

The suitability of groundwater for drinking (domestic), industrial, and irrigation (agricultural) purposes depends on its hydrogeochemical composition (Singh and Singh, 2008; Khodapanah et al., 2009). Under typical natural conditions, only a few of the solutes present in groundwater occur in concentrations greater than $1 \mathrm{mg} / \mathrm{l}$. These are generally referred to as the major ions and they comprise the cations $\mathrm{Ca}, \mathrm{Mg}, \mathrm{Na}$, and $\mathrm{K}$ and anions $\mathrm{HCO}_{3} / \mathrm{CO}_{3}, \mathrm{SO}_{4}$, $\mathrm{Cl}$, and $\mathrm{NO}_{3}$ (Drever, 1982).

Presently, almost all of the water used in domestic supply in Qatar is generated from seawater utilizing desalination plants and groundwater is vastly used for irrigated agriculture, especially in Northern Qatar where most of the Qatari farms are located.

This study thus attempts to evaluate the groundwater quality in Shamal area based on the analyses of hydrogeochemical parameters.

\subsection{Location of the Study Area}

The study area is located in the northern half of the Qatar peninsula, around Latitudes 


\section{Mll Macrothink}

$26^{\circ} 03^{\prime} 04.97^{\prime \prime} \mathrm{N}-26^{\circ} 04^{\prime} 31.05^{\prime \prime} \mathrm{N}$ and Longitudes $51^{\circ} 09^{\prime} 49.05^{\prime \prime} \mathrm{E}-51^{\circ} 19^{\prime} 48^{\prime \prime} \mathrm{E}$. It is very close to Al Ruwais at the extreme North.

\subsection{Geology and Hydrogeology}

The Qatar peninsula is underlain by a series of gently dipping to flat-lying sediments that were deposited on gradually subsiding basement rocks. The main geology of Qatar comprises Formations from Neogene and Paleogene periods, which are overlain by Quaternary deposits. The major structure of the peninsula is a broad north-south trending anticlinal arch with gentle crest and steeper marginal dips.

The oldest strata outcropping at the surface are the limestones of the Rus Formation which belong to the Early Eocene age, but the most widespread outcrops are the dolomites and crystalline chalky limestones in the upper part of the overlying Dammam Formation of Middle Eocene age. The Umm er Radhuma Formation of Paleocene age, directly underlies the Rus Formation throughout Qatar, but is not exposed at the surface. Mesozoic rocks have been identified during exploratory oil drilling by stratigraphic correlation with geological units in Saudi Arabia (Eccleston and Harhash, 1982).

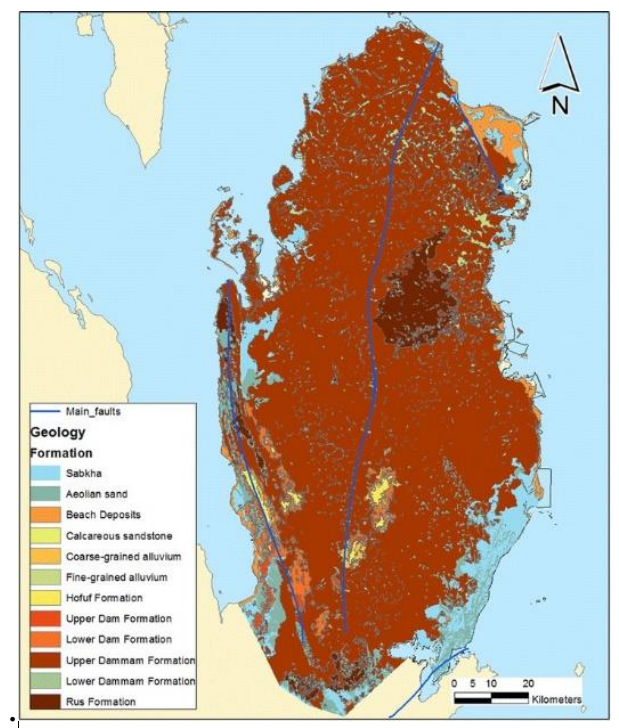

Fig 1. Surface geology of Qatar (after Baalousha, 2016)

The circulation of ground water is essentially controlled by climate, topography, geology and human activity. The water level in Qatar varies with respect to the mean sea level. It is about $9 \mathrm{~m}$ in the southern zone and about $4 \mathrm{~m}$ in the northern zone controlled by the hydrostatic head in Saudi Arabia. The water flows radially outwards from recharge areas centered over higher land surfaces in the northern and southern zones and discharges into the adjacent low lying sabkhas and the Arabian Gulf, reflecting changes in surface topographic features and the elevation of Qatar.

Annual rainfall in Qatar averages $80 \mathrm{~mm}$ and the spatial distribution decreases from North to South. The aquifers in the North are the major ones, with the lowest salt content. The water occurs in form of fresh water lenses sitting on top of more brackish and saline ground water. 


\section{Macrothink

Most groundwater wells (boreholes) exist in this basin.

The occurrence of fresh ground water in Qatar is restricted to the rocks of Eocene and Paleocene age.

The water table occurs in either the Dammam or Rus Formations over most of Qatar. Occurrence in the Dammam, however, is generally confined to the lower-lying coastal areas. The Rus aquifer and the Umm er Radhuma aquifer comprise a two-layer system that contains all of the fresh ground water available in Qatar.

\section{Method of Study}

Thirteen water samples were selected for the hydrogeochemical analysis of groundwater composition in the study area. Samples were collected in clean polyethylene bottles after pumping the wells for about five minutes to ensure stable conditions were attained. The samples were preserved appropriately for onward delivery to the Central Laboratories Unit of Qatar University. The $\mathrm{pH}$ was determined in-situ with a pocket $\mathrm{pH}-102$ meter (RoHS). A standard buffer solution was used to calibrate the $\mathrm{pH}$ meter before sampling. EC was also measured in-situ using the EC DiST-3 meter (HANNA, HI 98303). TDS was determined using the TDS-3 meter, TDS/TEMP (HM Digital). The relevant chemical analyses of the collected water samples were carried out according to the methods adopted by the U.S. Environmental Protection Agency (EPA) and the American Society for Testing and Materials (ASTM). The Metrohm USA IC system (Model \#850 Professional IC 850) was utilized for the analyses.

\section{Results}

The groundwater chemistry depends on different hydrogeochemical processes that the groundwater undergoes over space and time.

The table below summarizes the hydrogeochemical properties of the groundwater sampled from different wells within the study area. 


\section{Macrothink}

Environmental Management and Sustainable Development ISSN 2164-7682 2018, Vol. 7, No. 2

Table 1. Summary of the results for the hydrogeochemical parameters of the study area

\begin{tabular}{|c|c|c|c|c|c|c|c|c|c|c|}
\hline $\mathrm{S} / \mathrm{N}$ & LOCATION & TDS (mg/L) & E.C $(\mu \mathrm{S} / \mathrm{cm})$ & $\mathrm{Cl}^{-}(\mathrm{mg} / \mathrm{L})$ & $\mathrm{SO}_{4}{ }^{2-}(\mathrm{mg} / \mathrm{L})$ & $\mathrm{HCO}_{3}^{-}(\mathrm{mg} / \mathrm{L})$ & $\mathrm{Na}^{+}(\mathrm{mg} / \mathrm{L})$ & $\mathrm{K}^{+}(\mathrm{mg} / \mathrm{L})$ & $\mathrm{Ca}^{2+}(\mathrm{mg} / \mathrm{L})$ & $\mathrm{Mg}^{2+}(\mathrm{mg} / \mathrm{L})$ \\
\hline 1 & Dr. Aisha farm, Shamal & 5928.88 & 9263.88 & 2803.5 & 857.5 & 65.25 & 1611.74 & 83.3 & 355.58 & 152.01 \\
\hline 2 & Dr. Aisha farm, Shamal & 10332.01 & 16143.77 & 4654.23 & 1775.96 & 76.8 & 2729.62 & 128.65 & 666.78 & 299.97 \\
\hline 3 & Dr. Aisha farm, Shamal & 5050.80 & 7891.88 & 2177.75 & 970.83 & 32 & 1316.38 & 83.45 & 340.55 & 129.84 \\
\hline 4 & Dr. Aisha farm, Shamal & 9769.51 & 15264.86 & 4319.05 & 1787.72 & 54.36 & 2568.86 & 133.46 & 622.25 & 283.81 \\
\hline 5 & Dr. Aisha farm, Shamal & 5190.19 & 8109.67 & 2518.09 & 743.87 & 34.21 & 1392.55 & 74.00 & 300.81 & 126.66 \\
\hline 6 & Sakr Ahmed farm, Shamal & 9500.58 & 14844.66 & 3971.49 & 1942.98 & 181.14 & 2376.96 & 136.07 & 641.57 & 250.37 \\
\hline 7 & Sakr Ahmed farm, Shamal & 7708.51 & 12044.55 & 3434.69 & 1466.26 & 23.13 & 1991.46 & 116.08 & 473.72 & 203.17 \\
\hline 8 & Sakr Ahmed farm, Shamal & 8345.89 & 13040.45 & 3564.43 & 1609.72 & 121.34 & 2157.22 & 120.39 & 542.06 & 230.73 \\
\hline 9 & Shamal farm, Shamal & 13271.58 & 20736.84 & 5806.32 & 2448.79 & 221.32 & 3432.39 & 181.02 & 799.93 & 381.81 \\
\hline 10 & Shamal farm, Shamal & 11763.82 & 18380.97 & 5302.50 & 2160.87 & 137.23 & 2988.51 & 153.76 & 688.29 & 332.66 \\
\hline 11 & Shamal farm, Shamal & 7491.89 & 11706.08 & 3191.47 & 1408.43 & 120.23 & 1969.65 & 110.43 & 482.82 & 208.86 \\
\hline 12 & Shamal farm, Shamal & 7244.49 & 11319.52 & 3098.14 & 1353.09 & 120.02 & 1901.59 & 107.71 & 464.69 & 199.25 \\
\hline 13 & Al Shamal farm, Shamal & 11920 & 19280 & 6058 & 1050 & 240.3 & 3340 & 170.8 & 757.5 & 303.4 \\
\hline
\end{tabular}


The table below shows some statistical analysis of the hydrogeochemical properties.

Table 2. Descriptive statistics of the analyzed hydrogeochemical properties

\begin{tabular}{|l|l|l|l|l|l|}
\hline Parameters & No of samples & Minimum & Maximum & Mean & Standard Deviation \\
\hline $\mathrm{EC}(\mu \mathrm{S} / \mathrm{cm})$ & 13 & 7891.88 & 20736.84 & 13694.39 & 4017.07 \\
\hline $\mathrm{TDS}(\mathrm{mg} / \mathrm{L})$ & 13 & 5050.80 & 13271.58 & 8766.78 & 2513.98 \\
\hline $\mathrm{Cl}^{-}(\mathrm{mg} / \mathrm{L})$ & 13 & 2177.75 & 6058 & 3915.35 & 1194.70 \\
\hline $\mathrm{SO}_{4}^{2-}(\mathrm{mg} / \mathrm{L})$ & 13 & 743.87 & 2448.79 & 1505.84 & 496.28 \\
\hline $\mathrm{HCO}_{3}{ }^{-}(\mathrm{mg} / \mathrm{L})$ & 13 & 23.13 & 240.3 & 109.79 & 68.55 \\
\hline $\mathrm{Na}^{+}(\mathrm{mg} / \mathrm{L})$ & 13 & 1316.38 & 3432.39 & 2290.53 & 664.93 \\
\hline $\mathrm{K}^{+}(\mathrm{mg} / \mathrm{L})$ & 13 & 74.00 & 181.02 & 123.01 & 31.50 \\
\hline $\mathrm{Ca}^{2+}(\mathrm{mg} / \mathrm{L})$ & 13 & 300.81 & 799.93 & 548.96 & 155.24 \\
\hline $\mathrm{Mg}^{2+}(\mathrm{mg} / \mathrm{L})$ & 13 & 126.66 & 381.81 & 238.65 & 76.01 \\
\hline
\end{tabular}

\section{Discussion}

The two tables shown above are used for the interpretation and correlation of these hydrogeochemical parameters as outlined below.

\subsection{Total Dissolved Solids (TDS)}

The total concentration of dissolved minerals is a close approximation of the sum of the cations, anions and trace elements present in any groundwater sample. TDS is a good indicator of the suitability of groundwater for any specific purpose. The TDS of the samples studied ranges from 5050.80-13 271.58 mg/L, with a mean value of $8766.78 \mathrm{mg} / \mathrm{L}$. The table below after Freeze and Cherry (1979), shows the classification of water on the basis of TDS values.

Table 3. Nature of Groundwater Based on TDS Values (after Freeze and Cherry, 1979)

\begin{tabular}{|l|l|}
\hline TDS $(\mathrm{mg} / \mathrm{L})$ & Nature of water \\
\hline$<1000$ & Fresh water \\
\hline $1000-10000$ & Brackish water \\
\hline $10000-100000$ & Saline water \\
\hline$>100000$ & Brine water \\
\hline
\end{tabular}

From the table, it can be seen that nine of the water samples are brackish, while four other samples are saline. This suggests that most of the aquifers have been affected by mixing with more saline deeper waters rising to the upper regions.

\subsection{Electrical Conductivity (E.C)}

The electrical conductivity of water is the principal parameter used nowadays to measure a solution's salt content.

The electrical conductance of water measures its ability to conduct an electrical current. Fresh water has lower E.C than saline and brackish water. The E.C for the samples ranges from 7891.88-20 736.84 $\mu \mathrm{S} / \mathrm{cm}$, with a mean value of $13694.39 \mu \mathrm{S} / \mathrm{cm}$. 


\section{Macrothink}

The TDS and E.C are closely related as can be seen from the tables. Samples with high TDS have higher values of E.C. The high E.C values of the samples are indicative of high conductive water corresponding to saline and brackish waters.

\subsection{Calcium $\left(\mathrm{Ca}^{2+}\right)$}

Calcium occurs in abundance in the earth's crust and it is also one of the most common ions in groundwater. Calcium commonly occurs in precipitates, especially as precipitates of carbonate rocks typical of Qatar. The concentration of Calcium ions in the samples ranges from $300.81-799.93 \mathrm{mg} / \mathrm{L}$, with an average value of $548.96 \mathrm{mg} / \mathrm{L}$.

\subsection{Sodium $\left(\mathrm{Na}^{+}\right)$}

Sodium primarily infiltrates into groundwater from the release of soluble products during the weathering of plagioclase feldspars. The solution of halite finds importance in areas of evaporites deposits. The concentrations of $\mathrm{Na}^{+}$ions of the samples range from $1316.38-3432.39 \mathrm{mg} / \mathrm{L}$, with an average of $2290.53 \mathrm{mg} / \mathrm{L}$.

\subsection{Potassium $\left(K^{+}\right)$}

Potassium has the most abundance than other elements present in all the sedimentary rocks (Davis and DeWiest, 1966). Although the abundance of Potassium in the earth's crust is about the same as sodium, Potassium commonly has less than one tenth the concentration of Sodium present in natural water. The Potassium concentration of the samples studied ranges from $74.00-181.02 \mathrm{mg} / \mathrm{L}$, with a mean value of $123.01 \mathrm{mg} / \mathrm{L}$.

\subsection{Magnesium $\left(\mathrm{Mg}^{2+}\right)$}

Sedimentary sources of Magnesium include carbonates, such as dolomite. Magnesium has a solubility that is almost ten times more than Calcium, giving it a higher tendency to remain dissolved than Calcium. The concentrations of Magnesium in the studied samples range from $126.66-381.81 \mathrm{mg} / \mathrm{L}$, with a mean value of $238.65 \mathrm{mg} / \mathrm{L}$.

\subsection{Chloride $\left(\mathrm{Cl}^{-}\right)$}

Within the earth's crust, chloride occurs as a minor constituent but is however a major dissolved constituent of most natural water. Most chloride in groundwater comes from solution of halite and related minerals in evaporite deposits. The concentration of chloride in the samples range from $2177.75-6058 \mathrm{mg} / \mathrm{L}$, with an average of $3915 \mathrm{mg} / \mathrm{L}$. The chloride content is a significant anion in groundwater analysis.

The table below, after Stuyfzand (1989), classifies groundwater on the basis of its chloride content. 


\section{Macrothink}

Environmental Management and Sustainable Development

ISSN 2164-7682

2018, Vol. 7, No. 2

Table 4. Groundwater classification based on $\mathrm{Cl}$ in mg/l (after Stuyfzand, 1989)

\begin{tabular}{|l|l|}
\hline Main type & $\mathrm{Cl}(\mathrm{mg} / \mathrm{l})$ \\
\hline Very oligohaline & $<5$ \\
\hline Oligohaline & $5-30$ \\
\hline Fresh & $30-150$ \\
\hline Fresh-brackish & $150-300$ \\
\hline Brackish & $300-10^{3}$ \\
\hline Brackish-salt & $10^{3}-10^{4}$ \\
\hline Salt & $10^{4}-2.10^{4}$ \\
\hline Hyperhaline & $>2.10^{4}$ \\
\hline
\end{tabular}

From the table, groundwater in the study area fall under brackish-salt main groundwater types. This result closely agrees with the one obtained using TDS as the classification parameter.

\subsection{Sulphate $\left(\mathrm{SO}_{4}{ }^{2-}\right)$}

Sulphate in groundwater is derived mainly from the evaporite minerals gypsum (hydrous calcium sulphate, $\left.\mathrm{CaSO}_{4} \cdot 2 \mathrm{H}_{2} \mathrm{O}\right)$ and anhydrite $\left(\mathrm{Calcium}\right.$ Sulphate, $\left.\mathrm{CaSO}_{4}\right)$. The sulphate concentrations of the samples range from $743.87-2448.79 \mathrm{mg} / \mathrm{L}$, with an average of 1505.84 $\mathrm{mg} / \mathrm{L}$.

\subsection{Bicarbonate $\left(\mathrm{HCO}_{3}^{-}\right)$}

Most carbonate and bicarbonate ions present in groundwater are derived from the carbon dioxide (Davis and DeWiest, 1966); (Hem, 1970).

Groundwater generally contains between $10 \mathrm{mg} / \mathrm{L}$ to less than $800 \mathrm{mg} / \mathrm{L}$ bicarbonate concentrations. Concentrations between 50 and $400 \mathrm{mg} / \mathrm{L}$ are most common. Concentrations of carbonate ions are generally below $10 \mathrm{mg} / \mathrm{L}$ (Davis and De Wiest, 1966) and (Hem, 1970). For the studied samples, the bicarbonate concentration varies between $23.13-240.3 \mathrm{mg} / \mathrm{L}$, with an average of $109.79 \mathrm{mg} / \mathrm{L}$. Maximum concentration of bicarbonates may reflect natural leaching processes and dissolution of carbonate rocks.

\section{Analysis of Hydrogeochemical Ionic Ratios}

The table below summarizes the hydrogeochemical ratios of the studied water samples. 


\section{Macrothink}

Environmental Management and Sustainable Development

ISSN 2164-7682

2018, Vol. 7, No. 2

Table 5. Ratios of concentrations (mg/L) of dissolved species in the analyzed water samples

\begin{tabular}{|l|c|c|c|}
\hline \multirow{2}{*}{} & \multicolumn{2}{|c|}{ Hydrogeochemical coefficients } & \multirow{2}{*}{$\mathrm{Ca}^{+} / \mathrm{Mg}^{2+}$} \\
\cline { 2 - 3 } & $\mathrm{Na}^{+} / \mathrm{Cl}^{-}$ & $\mathrm{SO}_{4}{ }^{2-} / \mathrm{Cl}^{-}$ & \\
\hline Sample 1 & 0.57 & 0.31 & 2.34 \\
\hline Sample 2 & 0.59 & 0.38 & 2.22 \\
\hline Sample 3 & 0.60 & 0.45 & 2.62 \\
\hline Sample 4 & 0.59 & 0.41 & 2.19 \\
\hline Sample 5 & 0.55 & 0.30 & 2.37 \\
\hline Sample 6 & 0.60 & 0.49 & 2.56 \\
\hline Sample 7 & 0.58 & 0.43 & 2.33 \\
\hline Sample 8 & 0.61 & 0.45 & 2.35 \\
\hline Sample 9 & 0.59 & 0.42 & 2.10 \\
\hline Sample 10 & 0.56 & 0.41 & 2.07 \\
\hline Sample 11 & 0.62 & 0.44 & 2.31 \\
\hline Sample 12 & 0.61 & 0.44 & 2.33 \\
\hline Sample 13 & 0.55 & 0.17 & 2.50 \\
\hline Average value of Sea water & 0.90 & 0.1 & 0.2 \\
\hline Average value of River water & 1.80 & 1.6 & 3.7 \\
\hline Average value of study area & $0.55-0.62$ & $0.17-0.49$ & $2.07-2.62$ \\
\hline Average value of study area & 0.39 & 0.39 & 2.33 \\
\hline
\end{tabular}

The average values of sea and river water from Al-Ruwaih and Ben-Essa (2004)

$\mathrm{Na}^{+} / \mathrm{Cl}^{-}$ratios vary from $0.55-0.62$ with a mean value of 0.59 . The chloride ions occur at an approximate ratio of $1.7: 1$ compared to the sodium ions. The low values of the $\mathrm{Na}^{+} / \mathrm{Cl}^{-}$ratios indicate sea water contamination of the underlying groundwater.

$\mathrm{Ca}^{2+} / \mathrm{Mg}^{2+}$ ratios vary from $2.07-2.62$, with a mean value of 2.33 . These values show the relative abundance of calcium more than magnesium, the enrichment in calcium being an indication of the alteration of limestone to dolomite through dolomitization

$\mathrm{SO}_{4}{ }^{2+/} \mathrm{Cl}^{-}$ratios vary from $0.17-0.49$, with a mean value of 0.39 . This shows that chloride ion has a higher concentration than sulphate. This shortage of sulphate relative to chloride may indicate the absence of evaporites common in the Northern side of Qatar.

\subsection{Analysis of the Groundwater Samples for Irrigation Quality}

These characteristic properties of groundwater in the area are analyzed to determine its suitability for use as irrigation water.

\subsubsection{Electrical Conductivity (E.C)}

E.C is an indicator of TDS and a good measure of salinity hazard to crops. E.C between $2000-3000 \mu \mathrm{S} / \mathrm{cm}$ is doubtful for irrigation, while E.C above $3000 \mu \mathrm{S} / \mathrm{cm}$ is unsuitable. All the groundwater samples of the study area are above $3000 \mu \mathrm{S} / \mathrm{cm}$ and as such, are unsuitable for irrigation purposes. The high E.C values indicate corresponding high TDS values. 


\section{MIMacrothink}

\subsubsection{Kelly's Ratio}

Kelly's ratio is a measure of the level of $\mathrm{Na}^{+}$against $\mathrm{Ca}^{2+}$ and $\mathrm{Mg}^{2+}$. It is defined by

$$
K R=\frac{N a^{+}}{C a^{2+}+M g^{2+}}
$$

Groundwater with Kelly's ratio greater than 1 is generally considered as unsuitable for use in irrigation. The samples of the study area have K.R values ranging from 1.95-2.37 and are thus unsuitable for irrigation based on Kelly's ratio.

\subsubsection{Sodium Adsorption Ratio (SAR)}

This is a measure of the sodium hazard in relation to the concentrations of calcium and magnesium. It is given as:

$$
S A R=\frac{N a^{+}}{\sqrt{\frac{C a^{2+}+M g^{2+}}{2}}}
$$

SAR is used to forecast the probability of sodium accumulating in the soil. An alkali hazard is anticipated when SAR>6-9. All the samples studied show values above 9 and as such, permeability problems will be expected on shrinking and swelling types of clayey soils.

\subsubsection{Sodium Percentage $(\% \mathrm{Na})$}

When the sodium concentration is high in irrigation water, the sodium ions have a tendency to be absorbed by clay particles. This causes a displacement of magnesium and calcium ions, resulting in reduced permeability of the soil. The sodium percentage is calculated from:

$$
\% N a=\frac{\left(N a^{+}+K^{+}\right) * 100}{C a^{2+}+M g^{2+}+N a^{+}+K^{+}}
$$

All the groundwater samples studied fall under the doubtful water class based on $\mathrm{Na} \%$ for quality of irrigation water. In this classification, up to 20 is excellent, 20-40 is good, 40-60 is permissible, 60-80 is doubtful, while greater than 80 is unsuitable. The water samples studied have $\mathrm{Na} \%$ ranging from $66.86-70.92 \%$.

\subsubsection{Soluble Sodium Percent (SSP)}

SSP is also used to evaluate sodium hazard. It is defined as the ratio of sodium in epm to the total cation in epm expressed as a percentage. Water with $\mathrm{SSP}>60 \%$ may cause a sodium accumulation that will adversely alter the soil's physical properties. All the samples studied show SSP $>60 \%$ (64.86-68.77\%), and on that basis considered unsuitable for irrigation purposes.

\subsubsection{Potential Soil Salinity (PS)}

PS is defined by:

$$
P S=C l^{-}+\sqrt{S O_{4}^{2-}}
$$




\section{Macrothink}

Values of PS $>10$ epm are injurious-unsatisfactory for usage as irrigation water. The studied samples show PS values ranging from 65.84-175.32 epm which shows their unsuitability for irrigation.

\section{Conclusion}

The hydrogeochemical analyses of the water samples in the earea have shown that th groundwater of the area has high electrical conductivity and TDS values that render the water unfit for drinking and irrigation purposes. These high values, together with the high concentrations of $\mathrm{Na}$ and $\mathrm{Cl}$, indicate the problem of saline water intrusion in the area. The mass abundance of the major ions is in the order: $\mathrm{Na}>\mathrm{Ca}>\mathrm{Mg}>\mathrm{K}$ and $\mathrm{Cl}>\mathrm{SO}_{4}>\mathrm{HCO}_{3}$. Strong acid anions $\left(\mathrm{Cl}^{-}\right.$and $\left.\mathrm{SO}_{4}{ }^{2-}\right)$ exceed weak acid anion, $\mathrm{HCO}_{3}{ }^{-}$.

The concentrations of major anions and cations are higher than the permissible range for drinking and irrigation. The analysis of groundwater quality for irrigation by calculation of $\mathrm{KR}, \mathrm{SSP}, \% \mathrm{Na}$, SAR, PS and EC all yielded values exceeding the normal permissible range.

Similar studies should be undertaken in other areas in the northern part of the Qatar peninsula to ascertain the water quality and determine areas that have better quality for domestic and irrigation purposes.

Direct surface delivery, freshwater injection and increased recharge methods can be used to mitigate the effects of further saline intrusion. The novel approach of crystallization technology, which works by artificial induction of a crystallized solution that prevents seepage of saltwater through geologic units into the fresh water aquifers can be experimented to reduce further degradation of the water quality within Shamal and other parts of Northern Qatar.

\section{References}

Al- Ruwaih, F. M., \& Ben- Essa, S. A. (2004). Hydrogeological and hydrogeochemical study of the Al-Shagaya Field-F, Kuwait. Bulletin of Engineering Geology and the Environment, 63, 57-70. https://doi.org/10.1007/s10064-003-0213-6

AQUASTAT. (2011). Online database. Food and agriculture organization of the United Nations (FAO). Retrieved from http://www.fao.org/nr/water/aquastat/data/query/index.html

Baalousha, H. M. (2016). Development of a groundwater flow model for the highly parameterized Qatar aquifers. Model. Earth Syst. Environ, 2, 67.

https://doi.org/10.1007/s40808-016-0124-8

Davis, S. N., \& DeWiest, R. J. H. (1966). Hydrogeology. New York: John Wiley and Sons Inc.

Domenico, P. A., \& Schwartz, F. W. (1990). Physical and chemical hydrology. New York: John Wiley and Sons Inc.

Drever, J. I. (1982). The geochemistry of natural waters. Englewood Cliffs, New Jersey: Prentice-Hall Inc. 
Eccleston, B. L., \& Harhash, I. E. (1982). The hydrogeology of Qatar. FAO Project on Water Resources and Agricultural Development in Qatar, Phase III. Dept. of Agricultural and Water Research, Doha, Qatar, 173.

Fetter, C. W. (1994). Applied hydrogeology (3rd ed.). Upper Saddle River, New Jersey: Prentice-Hall Inc.

Freeze, R. A., \& Cherry, J. A. (1979). Groundwater. Englewood Cliffs, New Jersey: Prentice Hall Inc.

Gleeson, T., Wada, Y., Bierkens, M. F. P., \& van Beek, L. P. H. (2012). Water balance of global aquifers revealed by groundwater foot print. Nature, 488, 197-200.

https://doi.org/10.1038/nature11295

Kelley, W. P. (1940). Permissible composition and concentration of irrigation water. Proceedings of the American Society of Civil Engineers, 66, 607-613.

Kelley, W. P. (1951). Alkali soils, their formation, properties and reclamation. New York: Reinhold Publishing.

Khodapanah, N. (2009). Groundwater quality assessment for different purposes in Eshtehard District, Tehran, Iran. European Journal of Scientific Research, 36, 543-553.

Hem, J. D. (1970). Study and interpretation of chemical characteristics of natural water. U.S. Geological Survey, Water Supply Paper 1473, 363.

Powers, R. W., Ramirez, L. F., Redmond, C. D., \& Elberg, E. L. (1966). Geology of the Arabian Peninsula. U.S. Geological Survey Professional Paper No. 5600, 147.

Raj, V. K. (2004). Suitability of surface and groundwater for irrigation: a case study. National Geographical Journal, India, 50, 83-94.

Siebert, S., Burke, J., Faures, J., Frenken, K., Hoogeveen, J., Doll, P., \& Portmann, T. (2010). Groundwater use for irrigation - a global inventory. Hydrology and Earth System Sciences, 14, 1863-80. https://doi.org/10.5194/hess-14-1863-2010

Singh, V., \& Singh, U. C. (2008). Assessment of groundwater quality of parts of Gwalior (India) for agricultural purposes. Indian Journal of Science and Technology, 1, 1-5.

Stuyfzand, P. J. (1989). A new hydrochemical classification of water types. Proceedings of the International Association of Hydrological Sciences, 3, 33-42.

Todd, D. K., \& Mays, L. W. (2005). Groundwater hydrology (3rd ed.). New York: John Wiley and Sons Inc.

\section{Copyright Disclaimer}

Copyright for this article is retained by the author(s), with first publication rights granted to the journal.

This is an open-access article distributed under the terms and conditions of the Creative Commons Attribution license (http://creativecommons.org/licenses/by/3.0/). 